\title{
Penerapan Metode Fuzzy Tsukamoto untuk Menentukan Kualitas Proposal Layak Hibah
}

\author{
ABDUL HARIS \\ RIZQIA CAHYANINGTYAS \\ HENGKI SIKUMBANG \\ LUQMAN
}

Program Studi Teknik Informatika Sekolah Tinggi Teknik PLN

Menara PLN Jln. Lingkar Luar Barat Duri Kosambi Cengkareng Jakarta Barat Email: harismwakang@sttpln.ac.id, rizqia@sttpln.ac.id, hengkisikumbang3@gmail.com, luqman@sttpln.ac.id

\begin{abstract}
Abstrak. Penelitian ini bertujuan untuk mengembangkan suatu aplikasi pengajuan proposal Penelitian dan Pengabdian Masyarakat guna mempermudah proses pangajuan, monitoring dan evaluasi prosposal penelitian dengan menggunakan metode Fuzzy Tsukamoto, metode ini cukup mampu untuk untuk memetakan kualitas proposal yang layak hibah berdasarkan kategori yang telah ditetapkan. Selain itu, aplikasi ini dibuat untuk memperbaiki proses yang masih konvensional menjadi proses yang terkomputerisasi, mulai dari proses pengajuan sampai pada proses pelaporan. Selain itu, aplikasi ini juga mempermudah para reviewer untuk untuk memeriksa proposal dan laporan serta membantu pihak-pihak yang terkait. Dari hasil pengujian penerapan metode Tsukamoto, aplikasi ini menghasilkan akurasi yang cukup baik dengan tingkat kesalahan yang rendah. Namun, penerapan metode ini masih perlu pengukuran pembanding dengan penggunakan metode lain.
\end{abstract}

Kata Kunci: penelitian dan pengabdian masyarakat, tsukamoto, aplikasi

\begin{abstract}
This study aims to develop applications for research and community service proposals in order to facilitate the process of progress, monitoring and evaluation of prospective research using the Fuzzy Tsukamoto method. This method is sufficient to support the mapping process of the appropriate proposals quality based on the category- merit. In addition to that, the application is made to improve the conventional process into a process that is computed from the submission process to the reporting process. It also makes it easier for reviewers to access proposals and also help the parties concerned. From the results of testing the application of the Tsukamoto method in this application, it is found a fairly good verification with a low error rate but needs to be compared with the use of other methods.
\end{abstract}

Key words: Research and Community Service,Tsukamoto, Application

\section{PENDAHULUAN}

Perkembangan teknologi saat ini sangat cepat di setiap lini sudah banyak menggunakan teknologi termasuk dalam menyeleksi kualitas suatu karya ilmiah baik pada proses pengajuan proposal sampai pada mengukur kualitas laporan hasil penelitiannya beberapa penyedia dana hibah penelitian masih ada yang belum menggunakan sistem terkomputerisasi dalam melakukan seleksi proposal yang layak untuk menerima Hibah. Berbagai peneliti sudah membuat desain bahkan sudah ada hasil implementasinya bahkan berbagai metode telah digunakan seperti metode Simple Additive Weighting metode ini merupakan metode yang cukup sederhana dari hasil penelitian ini diketahui bahwa diperlukan pemilihan bobot yang tepat untuk 
mengoptimalkan hasil sehingga penggunaan metode ini perlu di Hybrid dengan metodemetode yang lain, namun dari aplikasi yang dihasilkan sudah berjalan dengan baik (Pangestika, 2016). Selain hasil penelitian tersebut juga telah dilakukan penelitian yang menggunakan metode Hybrid antara metode Analytical Hierarchy Process (AHP) dan Fuzzy Multi Criteria Decision Making (FMCDM) cara ini cukup baik dalam menghasilkan kriteri bobot karena ada metode yang dapat mengoptimalkan kriteria bobotnya sebelum penentuan hasil dan ada metode yang dapat menilai dan menentukan proposal yang baik namun pada penelitian ini masih terlalu kompleks karena kedua metode tersebut masih bisa digunakan tanpa harus di Hybrid dengan yang lainnya dari hasil penelitian ini masih cukup baik karena metode yang digunakan tersebut sudah mampu digunakan untuk menilai proposal, sintesa hasil keputusan dan penentuan peringkat proposal sebagai dasar ditolak atau diterima sebuah proposal namun pada penelitian ini belum diterapkan dalam bentuk implementasi kedalam software dan Teknik pengujian belum sampai pada pengujian software (Ariyanto.R, 2014). Dari beberapa penelitian selanjutnya masih diperlukan kajian-kajian ilmiah ataupun pengujian hasil dengan metode-metode yang lainya seperti yang telah dilakukan dalam penelitiannya membangun sistem informasi P2M fakultas Teknik Universitas Sebelas Maret bahwa membangun sebuah Aplikasi berbasis web itu utama diperlukan Input, proses pencarian, pengolahan data dan harus mampu melayani pengguna dengan baik (Muflich, 2011). Di samping itu penelitian yang dilakukan oleh (Haris, Syahra, 2015) bahwa dalam membangun sebuah sistem aplikasi dibutuhkan beberapa tahapan mulai dari Analisa kebutuhan, desain sampai menghasilkan informasi membutuhkan sebuah cara atau metode yang tepat agar mampu menghasilkan informasi yang akurat. Pada kajian ini menggunakan metode Fuzzy Tsukamoto untuk melakukan Analisa sampai ke informasi yang dihasilkan karena metode ini telah dibuktikan tercapai apa telah menjadi tujuan dalam penelitian(Rakhmat Wahyu W1, 2009), sehingga metode ini dirasa cukup akurat untuk menghitung deskevaluasi sampai pada monitoring hasil, pada penelitian ini target yang ingin dicapai adalah riset yang akan dilakukan mencapai akurasi $100 \%$ untuk seleksi proposal dengan data sampel 20 buah proposal dengan memberi peringkat yang mendapat peringkat tertinggi merupakan proposal yang layak untuk menerima hibah yang diukur berdasarkan 2 parameter yaitu dengan melakukan Fuzzyfikasi dan menentukan basis fuzzy-nya.

\section{METODE}

Dalam penyelesaian masalah pada diperlukan Analisa kebutuhan terelebih dahulu dengan memetakan bisnis proses pemilihan proposal layak hibah dengan menentukan alurnya maka pertama-tama proposal harus melewati tahap penilaian desk evaluasi dan tahap penilaian monitoring evaluasi yang dilakukan oleh reviewer. Berikut tahapan penerapan Metode Tsukamoto (a) Fuzzyfikasi adalah sebuah proses untuk mengubah input sistem yang mempunyai nilai tegas menjadi sebuah variabel linguistic menggunakan suatu fungsi keanggotaan yang dapat disimpan dalam basis pengetahuan fuzzy. (b) pembentukkan Basis Pengetahuan Fuzzy adalah kumpulan rule-rule Fuzzy dalam bentuk pernyataan IF-THEN. (c) Fungsi implikasi Max-Min atau Dot-Product adalah suatu proses untuk merubah input fuzzy kedalam output fuzzy dengan mengikuti aturan aturan IF-THEN Rules yang sudah ditetapkan untuk mendapatkan $\alpha$-predikat tiap-tiap rule $(\alpha 1, \alpha 2, \alpha 3, \ldots \ldots, \alpha)$. Kemudian masing masing nilai $\alpha$-predikat ini digunakan untuk menghitung keluaran hasil inferensi secara tegas (Crisp) masing-masing rule $(\mathrm{z} 1, \mathrm{z} 2, \mathrm{z} 3, \ldots \ldots . \mathrm{zn})$. (d) Defuzzyfikasi adalah mengubah output fuzzy yang didapat dari mesin inferensi untuk dijadikan nilai tegas menggunakan fungsi keanggotaan yang sesuai pada saat dilakukan fuzzyfikasi. Dari tahapan-tahapan pada metode tersebut dapat dibuat skenario rancangan sistem yang nantinya digunakan untuk memvisualisasi sistem sebagai berikut: 


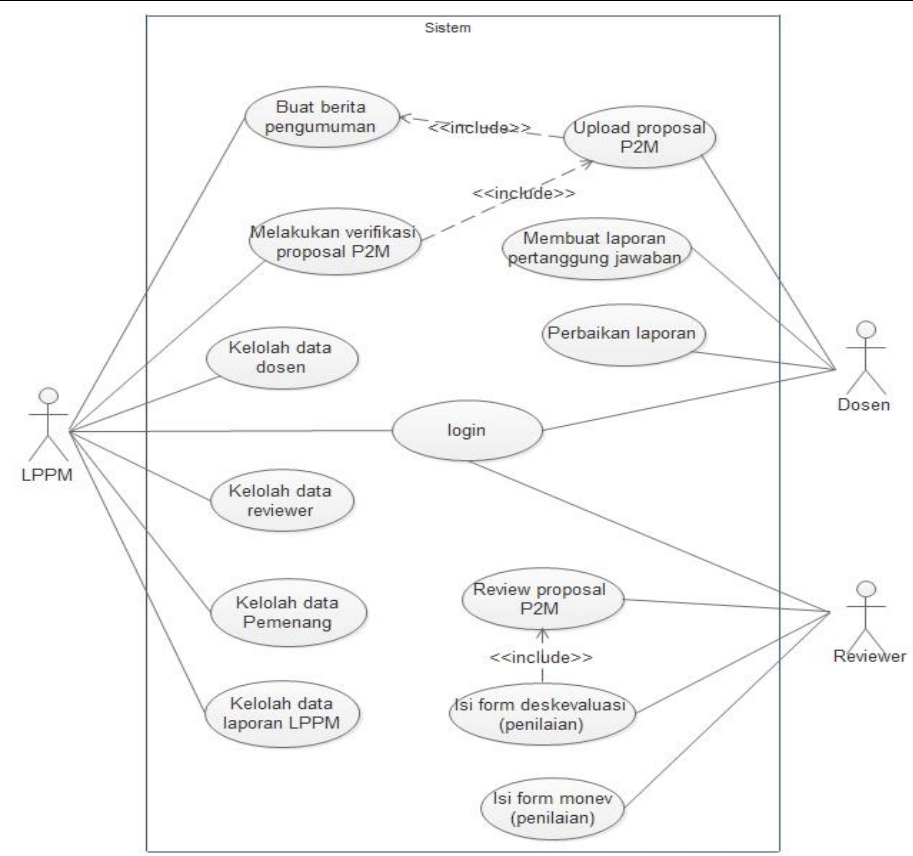

Gambar 1. Rancangan Sistem dengan Use Case Diagram

Dari rancangan diatas dapat diturunkan menjadi beberapa turunan seperti penggunaan class diagaram yang menggambarkan hubungan antar class dari objek-objek yang terdapat dalam sistem kemudian dari Class Diagram tadi diturunkan menjadi Activity Diagram dan Sequence Diagram dari kesemua diagram tersebut akan menggambarkan sistem yang akan dibangun. Setelah dilalui tahapan diatas maka akan di uji keandalan sistem menggunakan metode pengjian User Acceptance Test pengujian ini dilakukan untuk mengetahui penerimaan pengguna terhadap sistem yang dibangun.

1. Metode Tsukamoto

Metode Tsukamoto merupakan metode yang akan digunakan dalam aplikasi seleksi metode ini yang digunakan untuk melakukan untuk melakukan seleksi proposal secara otomatis yang diajukan peneliti. Pada metode ini setiap konsekuen pada aturan yang berbentuk IF-THEN harus direpresentasikan dengan suatu himpunan fuzzy dengan fungsi keanggotaan yang monoton. Output hasil inferensi dari tiap-tiap aturan diberikan secara tegas (Crisp) bedasarkan $\alpha$-predikat (fire strength) seperti yang telah dijelaskan diatas. Proses agregasi antar aturan dilakukan, dan hasil akhirnya diperoleh dengan menggunakan Defuzzy dengan konsep rata-rata terbobot.

$$
\begin{aligned}
& \text { if }(X \text { is } A) \text { and }(Y \text { is } B) \\
& \text { if }(X \text { is } A 1) A N D(Y \text { is } B 1) \text { Then ( } Z \text { is } C 1) \\
& \text { if }(X \text { is } A 2) A N D(Y \text { is } B 2) \text { Then }(Z \text { is } C 2)
\end{aligned}
$$

Dimana A, B, C adalah himpunan fuzzy.

Pada grafik berikut adalah bentuk grafik pada tahapan penilaian deskevaluasi dan penilaian monitoring evaluasi pada pengajuan proposal: 


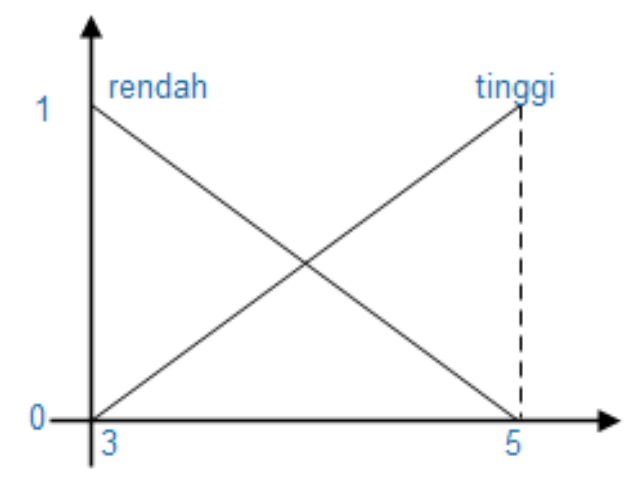

Gambar 2 Grafik Penilaian Deskevaluasi dan Penilaian Monitoring Evaluasi

Pada gambar grafik diatas menggunakan kurva linear naik dan kurva linear turun. kurva turun menunjukkan derajat keanggotaan rendah sedangkan kurva naik menunjukkan derajat keanggotaan tinggi, artinya jika mendapatkan nilai dibawah 3 maka nilainya termasuk ke dalam kurva rendah, jika mendapatkan nilai diatas 3 makan nilainya termasuk ke dalam kurva tinggi. Nilai domain 3 dan 5 tersebut merupakan standart ketentuan, nilai domain tersebut akan digunakan untuk mencari nilai derajat keanggotaan pada tahap mesin inferensi. Menggunakan kurva linear karena nilainya konstant atau pasti. kemudian pada grafik berikutnya dapat dilihat hasil dalam bentuk kurva sebagai berikut:

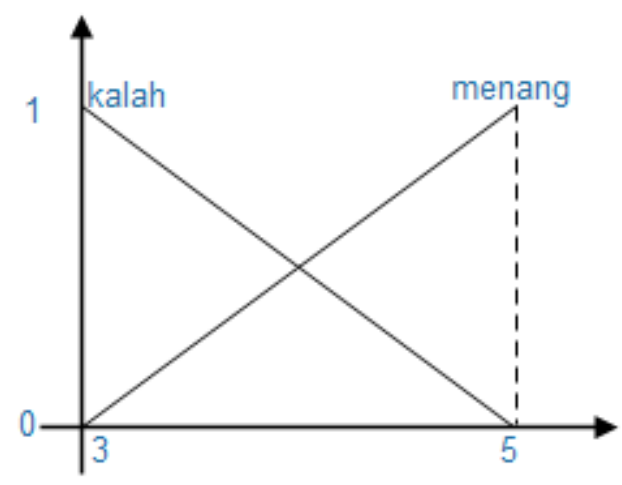

Gambar 3 Penentuan proposal yang diterima

Pada kurva ini juga menggunakan kurva linear naik dan kurva linear turun. Kurva turun menunjukkan derajat keanggotaan kalah sedangkan kurva naik menunjukkan derajat keanggotaan menang, artinya jika mendapatkan nilai dibawah 3 maka nilainya termasuk ke dalam kurva kalah, jika mendapatkan nilai diatas 3 maka nilainya termasuk ke dalam kurva menang. Nilai domain 3 dan 5 tersebut merupakan standart ketentuan dan nilai domain tersebut akan digunakan untuk mencari nilai derajat keanggotaan pada tahap mesin inferensi.

\section{HASIL DAN PEMBAHASAN}

Pada proses yang telah diteliti dan mendapatkan hasil dari metode yang digunakan pada aplikasi yang dibangun berbasis web seperti yang terdapat pada gambar 1 dan dapat dilihat setiap langkah yang telah dilakukan berdasarkan aturan Tsukamoto adalah melakukan fuzzyfikasi dan pembentukan basis fuzzynya dengan langkah pertama pembentukan berdasarkan tahapannya. Basis fuzzy dibuat dalam bentuk kumpulan Rule fuzzy dalam bentuk pernyataan IF Then. Penentuan pemenang ditentukan oleh kombinasi rule antara penilaian deskevaluasi dengan monev. 
[R1] IF nilai deskevaluasi RENDAH and nilai monev TINGGI then KALAH; [R2] IF nilai deskevaluasi RENDAH and nilai monev RENDAH then KALAH;

[R3] IF nilai deskevaluasi TINGGI and nilai monev TINGGI then MENANG;

[R4] IF nilai deskevaluasi TINGGI and nilai monev RENDAH then KALAH;

Tabel 1. Data Uji Coba

\begin{tabular}{llcc}
\hline \multicolumn{1}{c}{ Judul Penelitian } & $\begin{array}{c}\text { Nilai } \\
\text { Deskeva }\end{array}$ & $\begin{array}{c}\text { Nilai } \\
\text { Monev }\end{array}$ \\
\hline A1 & $\begin{array}{l}\text { Pengembangan Sistem Monitoring PLTS untuk Smart } \\
\text { Power Plan berbasis IoT dan Syaraf Buatan }\end{array}$ & 3,95 & 3,75 \\
A2 & $\begin{array}{l}\text { Peningkatan Kualitas Pembelajaran Dengan Perbaikan } \\
\text { Dan Pemeliharaan Tempat Ibadah dan Kelas Bersih }\end{array}$ & 4,2 & 3,25 \\
$\begin{array}{l}\text { Pada Siswa Madrasah As Solihin Cipondoh Tangerang } \\
\text { Banten }\end{array}$ & & \\
A3 Ponitoring Penggunaan Energi Listrik Pada & 3,65 & 3,75 \\
& $\begin{array}{l}\text { Pembangkit Listrik Tenaga Surya Untuk Pengelolahan } \\
\text { Energi Listrik Kerakyatan }\end{array}$ & & \\
A4 $\begin{array}{l}\text { Aplikasi identifikasi suara menggunakan metode Fast } \\
\text { Fourier Transform dan K-Nearest Neighbor pada } \\
\text { Android }\end{array}$ & 3,65 & 3,75 \\
Pengembangan dan Pemanfaatan Simulasi Model & 3,9 & 3,25 \\
\hline
\end{tabular}

Kemudian pada deskevaluasi dan monitoring evaluasi memiliki fungsi keanggotaan yang sama. Fungsi keanggotan ini berasal dari kurva yang digunakan yaitu kurva linear turun derajat keanggotaanya rendah dan kurva linear naik derajat keanggotannya tinggi fungsi keanggotannya yang digunakan sesuai dengan kurva linear diatas dapat dibuat dengan rentang nilai 3 dan 5 untuk mendapat nilai tinggi dan nilai rendeh dengan persamaan nilai dari kurva Deskevaluasi sebagai berikut:

$$
\begin{aligned}
& \text { urendah }[x]=\left\{\begin{array}{lr}
1 ; & x \leq 3 \\
(5-x) /(5-3) ; & 3 \leq x \leq 5 \\
0 ; & x \geq 5
\end{array}\right. \\
& \mu \text { tinggi }[x]=\left\{\begin{array}{lr}
0 ; & x \leq 3 \\
(x-3) /(5-3) ; & 3 \leq x \leq 5 \\
1 ; & x \geq 5
\end{array}\right.
\end{aligned}
$$

Untuk menentukan nilai hasil deskevaluasi diatas nilai rendah dengan menggunakan $(5-x) /(5-3)$ dengan kondisi $3 \leq x$ dan $x \leq 3$ atau $x \leq 5$ atau $x \geq 5$ atau kondisi nilai tinggi dengan menggunakan $(x-3) /(5-3)$ dengan kondisi $3 \leq x$ dan jika $x \leq$ 3 atau $x \leq 5$ atau $x \geq 5$ sehingga dari persamaan tersebut kemudian dilakukan tahapan menentukan inferensi dengan cara mengubah input fuzzy kedalam ouput dengan mengikuti aturan IF THEN rules, pada tahap ini digunakan operasi irisan (sering disebut operator AND) dari himpunan fuzzy A dan B dinyatakan sebagai $\mathrm{A} \cap \mathrm{B}$. Operasi irisan disebut sebagai Min. Karena pada rules menggunakan operator AND, maka digunakan $\cap$ dan operasi Min. kemudian dari hasil proses tersebut didapatkan nilai seperti yang tersaji pada tabel berikut: 
Tabel 2. Nilai Deskevalasi dari Derajat keanggotaan

\begin{tabular}{lrrr}
\hline Himp & \multicolumn{1}{c}{$\begin{array}{c}\text { Nilai } \\
\text { Deskeva }\end{array}$} & $\begin{array}{c}\text { Derajat keanggotaan } \\
\text { rendah }\end{array}$ & $\begin{array}{c}\text { Derajat keanggotaan } \\
\text { tinggi }\end{array}$ \\
\hline A1 & 3,95 & 0,525 & 0,475 \\
A2 & 4,2 & 0,4 & 0,6 \\
A3 & 3,65 & 0,675 & 0,325 \\
A4 & 3,65 & 0,675 & 0,325 \\
A5 & 3,9 & 0,55 & 0,45 \\
\hline
\end{tabular}

Kemudian pada tahapan selanjutnya adalah mementukan nilai derajat keanggotaan monitoring evaluasi dengan menggunakan rumus kurva penilaian dan fungsi keanggotaan monitoring evaluasi seperti pada persamanaan monitoring evaluasi dibawah ini:

$$
\begin{aligned}
& \mu \text { rendah }[x]=\left\{\begin{array}{lr}
1 ; & x \leq 3 \\
(5-x) /(5-3) ; & 3 \leq x \leq 5 \\
0 ; & x \geq 5
\end{array}\right. \\
& \mu \text { tinggi }[x]=\left\{\begin{array}{lr}
0 ; & x \leq 3 \\
(x-3) /(5-3) ; & 3 \leq x \leq 5 \\
1 ; & x \geq 5
\end{array}\right.
\end{aligned}
$$

Untuk menentukan nilai rendah menggunakan $(5-x) /(5-3)$ dengan rentang berada diantara 0 dan 1 dengan kondisi jika $3 \leq x$ dan kondisi $x \leq 3$ atau $x \leq 5$ atau $x \geq 5$ untuk nilai tinggi dan $(5-3) /(5-3)$ dengan kondisi $x \leq 3$ atau $x \leq 5$ atau $x \geq 5$ sehingga persamaan tersebut di inferensikan hasilnya seperti yang terdapat dalam tabel dibawah ini:

\begin{tabular}{|c|c|c|c|}
\hline Himp & $\begin{array}{l}\text { Nilai } \\
\text { Monev }\end{array}$ & $\begin{array}{l}\text { Derajat keanggotaan } \\
\text { rendah }\end{array}$ & $\begin{array}{c}\text { Derajat keanggotaan } \\
\text { tinggi }\end{array}$ \\
\hline A1 & 3,75 & 0,625 & 0,375 \\
\hline A2 & 3,25 & 0,875 & 0,125 \\
\hline A3 & 3,75 & 0,625 & 0,375 \\
\hline A4 & 3,75 & 0,625 & 0,375 \\
\hline A5 & 3,25 & 0,875 & 0,125 \\
\hline
\end{tabular}

Tabel 3. Nilai Hasil Monitoring dengan Derajat keanggotaan

Langkah selanjutnya adalah mengubah output fuzzy yang didapat dari perhitungan diatas untuk dijadikan nilai tegas menggunakan fungsi keanggotaan yang sesuai pada saat dilakukan fuzzyfikasi berikut perhitungannya menggunkan rumus rata-rata:

$$
z=\frac{\sum \alpha \text { pred } . z}{\sum \alpha \text { pred }}
$$


Kemudian dilakukan

$$
\begin{aligned}
z & =\frac{\alpha \text { pred }_{1} * z_{1}+\alpha \text { pred }_{2} * z_{2}+\alpha \text { pred }_{3} * z_{3}+\alpha \text { pred }_{4} * z_{4}}{\alpha \text { pred }_{1}+\alpha \text { pred }_{2}+\alpha \text { pred }_{3}+\alpha \text { pred }_{4}} \\
& =\frac{(0,125 \times 4,75)+(0,55 \times 3,9)+(0,125 \times 3,25)+(0,45 \times 4,1)}{(0,125+0,55+0,125+0,45)} \\
& =\frac{0,59375+2,145+0,40625+1,845}{1,25} \\
& =\frac{4,99}{1,25} \\
& =3,992 \text { di bulatkan menjadi } 3,99
\end{aligned}
$$

Setelah melakukan pengujian dengan sampel 20 proposal dengan menggunakan Teknik pengujian User Acceptance Test mencapai hasil $100 \%$ baik dengan data uji proposal mencapai 20 proposal keatas dan sudah sesuai dengan yang diharapkan namun dalam paper ini data yang digunakan sebagai sampel hanya 5 proposal maka akan menghasilkan.

$$
\text { Persentase }=\frac{5}{5} x 100 \%=100 \%
$$

\section{PENUTUP}

\section{Simpulan}

Dari hasil uaraian diatas dapat disimpulkan bahwa dari tahap awal hingga proses pengujian, dengan adanya Aplikasi ini dapat disimpulkan bahwa :

1. Aplikasi berbasis website ini akan memudahkan proses seleksi proposal dalam pengolahan data sampai dengan pelaporan hasil yang akan dipilih.

2. Dapat memudahkan dosen dalam pengajuan proposal Penelitian dan Pengabdian Masyarakat, pengumpulan laporan akhir dan memperoleh informasi mengenai penelitian dan pengabdian masyarakat secara lebih akurat dan lebih tepat.

3. Pada sistem ini dapat mempermudah pengelola untuk dapat melihat langsung nilai masing-masing dari penilaian deskevaluasi dan monitoring evaluasi yang sudah dinilai oleh reviewer.

4. Penerapan metode perhitungan fuzzy Tsukamoto dalam sistem aplikasi ini dapat membantu dalam penentuan pemenang yang nilainya diambil dari penilaian deskevaluasi beserta monev.

5. Dibandingkan dengan penelitian sebelumnya adalah penelitian ini telah menghasilkan Aplikasi yang dapat gunakan.

\section{Saran}

Untuk aplikasi dengan menggunakan metode ini perlu ada pengembangan yang lebih baik mengingat aplikasi ini perlu mencoba di hybrid dengan metode lain untuk pengujian dan pembenahan pada aplikasi karena pada aplikasi yang dihasilkan.

\section{DAFTAR PUSTAKA}

Ariyanto.R, A. (2014). Rancang Bangun Sistem Pendukung Keputusan Kelompok untuk Seleksi Proposal Penelitian Hibah Bersaing ( Studi Kasus : UPT P2M Politeknik Negeri 
Malang ), 24(2), 193-205.

Haris, Abdul, Syahra, T. (2015). Implementasi Sistem Layanan Informasi Akademik Terintegrasi Web [STUDI KASUS: SMK Teknologi Plus Padjadjaran Sukabumi]. Jurnal Teknik, 3, 111-131.

Muflich, F. (2011). Pengembangan Sistem Informasi Berbasis Web Untuk Pengelolaan Data Penelitian Dan Pengabdian Kepada Masyarakat ( P2M).

Pangestika, W. W. (2016). Sistem Informasi Pengabdian Kepada Masyarakat (P2M) Internal Pada Lembaga Penelitian Dan Pengabdian Kepada Masyarakat (LPPM) STT-PLN.

Rakhmat Wahyu W1, L. A. (2009). Aplikasi Fuzzy Inference System ( Fis ) Metode Tsukamoto Pada Simulasi Traffic Light Menggunakan Java, 2009(Snati), 104-107. 